\title{
THE REPRESENTATION OF WOMEN IN HOSPITALITY JOURNAL EDITORIAL BOARDS
}

\author{
Delly M. Chatibura ${ }^{1}$ \\ Nametsegang Motshegwa ${ }^{2}$ \\ Montle, K. C. Siya ${ }^{3}$
}

\begin{abstract}
Despite their proven abilities as leaders, women continue to be marginalized at both local and global levels. Even in the academic field, the issue of gender disparity, which hampers women's advancement in rank and responsibility, has attracted the interest of several studies for decades. In an effort to study the issue of gender parity, this paper documents the extent of women representation in the editorial boards of ten leading hospitality academic journals, reviewing the functions of women at various editorial levels. The paper builds upon previous research in tourism and hospitality and in the fields of management, marketing, medicine and economics, to name a few. To achieve this, an exploratory research design was used where manual data collection and quantitative analysis was employed. Some of the findings reveal that only 132 (of 624) editorial members were women, holding management, editor and other positions in the board: an important consideration that reflects the issue of gender disparity in hospitality journal editorial boards. The majority of these positions were held at professorial rank and were affiliated with American universities. Their presence on the boards, was mainly influenced by the size of the board, the age of the journal and the women's research productivity.
\end{abstract}

Keywords: gender parity, hospitality field, academic journals

\section{INTRODUCTION}

The majority of studies that have analyzed the influence of women in academia and to some extent gender parity or imbalance, specifically at journal editorship level have been carried out in economics (e.g. Addis \& Villa, 2003), management (e.g. Metz \& Harzing, 2012), medical (e.g. Ioannidou \& Rosania, 2015; Kennedy, Lin \& Dickstein, 2001), marketing (e.g. Pan \& Zhang, 2014), mathematical sciences (Topaz \& Sen, 2016) and other science journals (e.g. Meyer, Cimpian \& Leslie, 2015), to mention a few. Our study presents a point of departure, by specifically relating to women editorship in the field of hospitality. Although a similar study was conducted by Munar et al. (2015), on editorships in tourism and hospitality journals,

\footnotetext{
${ }^{1}$ Senior Lecturer, Department of Tourism and Hospitality Management, University of Botswana, Botswana, mahachid@ub.ac.bw

${ }^{2}$ Lecturer, Department of Tourism and Hospitality Management, University of Botswana, Botswana, motshegwan@ub.ac.bw

${ }^{3}$ Lecturer and Head, Department of Tourism and Hospitality Management University of Botswana, Botswana, siyamkc@ub.ac.bw
} 
Gursoy and Sandstrom (2016) argue for the disaggregation and differentiation of the two fields. This approach, aids researchers gain a more accurate understanding of the relative importance of each field's set of journals (McKercher, Law \& Lam, 2006). The hospitality field is peculiar at three levels. At the graduate student level, female students dominate tourism and hospitality graduate cohorts in areas such as Asia and Australia (King, McKercher \& Waryszak, 2003). At the same time, this number is increasing (Woods \& Viehland, 2000). Although values may differ, at industry level, hospitality is predominantly female-dominated in Spain and in the United States, as women account for 54\% (Santero-Sanchez et al., 2015) and 51\% of the labour force (Young, 2017) respectively. At authorship level (without specific statistics for hospitality), the majority of the 3370 tourism and hospitality authors on the International Centre for Research and Study on Tourism (CIRET) and the Tourism Research Information Network (TRINET) databases whose gender could be ascertained, were men, at 59\% (Munar et al. 2015).

Although there is ensuing debate on what proportions should be expected, for an editorial board, the percentage of female editorial board members can be mirrored to the percentage of female authors in the corresponding journals, women in faculty or female members in professional associations (Mauleón \& Hillán, Moreno, Gómez \& Bordons, 2013). In the case of this article, the authors selected to comply with an expectation in line with authorship in tourism and hospitality journals, as indicated by Munar et al. (2015) that depicts a disparity in favour males. The authors were thus interested in noting whether such a tendency would be mirrored in the editorial boards of hospitality journals. In line with this endeavor, the present article therefore aims to:

1. Document the extent of women representation in the editorial boards of leading hospitality journals using the existing disparity of gender representation in tourism and hospitality academia as a proxy.

2. Review the roles of women in leading hospitality journal boards.

3. Highlight factors that influence the presence of women in the boards.

This paper helps advance existing literature in hospitality, by highlighting the factors that could influence the presence of women in journal editorial boards. The following section presents the literature that was reviewed to guide the study. 


\section{LITERATURE REVIEW}

Gender is a key characteristic of membership to journal editorial boards, amongst others such as nationality and research standing (Willet, 2013). The representation of women in the editorial boards of academic journals has been recorded as far as the 1980s. Over (1981) for instance, studied the sex ratio of the editorial boards of 14 psychology journals, noting an increase from $6.8 \%$ in 1972 to $17.8 \%$ in 1977 , of women editorial appointments. There was also a substantial increase in women representation on the boards of major medical journals between 1970 and 2005 (Jagsi et al., 2008) and psychology and management journals (Mauleón et al., 2013). This increase has also been recorded even at prestige positions of editor-in-chief in medical journals (Jagsi et al., 2008). Despite such increases, most studies confirm the low or under representation of women in comparison to their male counterparts, signaling gender disparity. The ratio of women to men, often used to measure the gender gap and gender parity in journal editorial boards, is obtained by dividing the percentage of women with that of men (Mauleón et al., 2013). The ratio when below or above 1, indicates gender disparity in favour of men and women respectively. A ratio of 1 suggests gender parity (Mauleón et al., 2013). The representation of women in the editorial boards of marketing journals was low, with $24 \%$ of them serving as board members and 22\% as editor-in-chiefs (Pan \& Zhang, 2014).

In the mathematical sciences women editors were underrepresented in comparison to their proportion in the field (Topaz \& Sen, 2016). In the United States women in the mathematical sciences accounted for $29 \%$ of doctoral holders and $15 \%$ of tenure stream faculty, whilst in editorial boards they accounted for $8.9 \%$. A study by Ioannidou and Rosania (2015) of 3060 editors in dental journals, portrayed similar underrepresentation of women compared to their proportion as faculty members, as they represented $2.5 \%$ of editor-in-chiefs and $16.0 \%$ of associate editors-in-chief. By comparing women on editorial boards of medical journals with their representation as physicians in their respective specialties, Kennedy, Lin and Dickstein (2001) also noted disparity in more than half of the journals studied.

The proportion of women (to men) as editorial members varies by journal and discipline (Mauleón et al., 2013). However, the generalisation is towards gender disparity in favour of men even in some specialties that are dominated by women professionally. The factors that have influenced women presence on editorial boards are multitude. They range from the presence of women editors-in-chief on the board, journal features such as the size of the editorial board, the Scimago Journal and Country Rank (SJR) position and journal internationalisation (Mauleón et al., 2013) to mention a few. 
Prior research confirms that the presence of a woman editor-in-chief increases the participation of women as editorial and advisory members (Ioannidou \& Rosania, 2015). Mauleón et al. (2013) found a positive correlation between female editor-inchiefs and women presence in the editorial board. This paper also envisaged that:

$H_{1}$ : Hospitality journals with women editors-in-chief have a higher number of women in the editorial board.

$\mathrm{H}_{2}$ : The presence of women at management editorship position is positively correlated with the presence of women in the editorial board.

Kennedy, Lin and Dickstein (2001) further purport that the presence of women on the editorial board assists in the academic advancement of other women by increasing the articles for publication that are written by them. In the medical field as they argue, this can encourage the publication of papers on women's issues. The presence of a female editor was found to be positively associated with the percentage of articles authored/coauthored in marketing journals.

Mauleón et al. (2013) found no relationship between female presence (either as authors or editorial board members) and the prestige of the journal (measured by its SJR position) and internationalisation (measured by the percentage of foreign articles published in the journal). However, they noticed that female presence in editorial boards was positively correlated with the size of the editorial board. In this paper it was also hypothesized that:

$H_{3}$ : The size of an editorial board is positively correlated with the number of women in the editorial board.

Although Brinn and Jones (2007; pg. 4) noted little evidence suggesting that membership to accounting editorial boards was influenced by institution of affiliation or geographical spread, but rather members were drawn from a 'selfperpetuating elite' group of graduates from the top United States universities, the geographic region of affiliation was found to be influential in promoting women editorship by Metz and Harzing (2012). Metz and Harding's (2012) study of management editorial boards indicated that women had a lower chance of becoming editors-in-chief in European or Australasian based journals than in journals based in the United States. They argue that United States based management journals have always had the most diverse editorial boards since 1989 (p. 295). In this light, this paper purported that: 
$H_{4}$ : The geographic region of a hospitality journal's affiliation has an influence on the presence of women in the editorial boards.

The study also hypothesized that:

$H_{5}$ : Women from universities affiliated with certain geographic regions have a higher presence in leading hospitality journals.

Another factor influential in promoting women editorships is the age of the journal. The age of the journal is 'calculated by subtracting the year the journal was established from the year of data collection' (Metz \& Harzing, 2009, p. 547). Mertz and Harzing (2009) found modest positive correlation between the age of management journals and female membership in the editorial boards. Eighty-three percent of the marketing journals analyzed by Pan and Zhang (2014) witnessed an increase in women representation on their editorial boards over a period of 15 years. The Business Horizon journal, for instance, that had no women representation in 1997, had 33\% in 2012 (Pan \& Zhang, 2014). Mauleón et al. (2013) also noted an upward trend in the percentage of female editorial members between 1998 and 2009, being significantly higher in the most recent year. This paper therefore hypothesized that:

$H_{6}$ : The age of a hospitality journal is positively correlated with the presence of women in the editorial boards.

Two other important factors that were analyzed in this paper, that have an influence on the presence of women in editorial boards was the academic rank of the female editors and their research productivity (measured by the $g$-index). The nomination to serve on an editorial board is a prestigious honour (Brinn \& Jones, 2007). Editors hold positions of power and the editorial decisions they make can influence the course of research within a community (Topaz \& Sen, 2016). For women, nomination serves as a measure of their influence at academic level (Gollins, Shipman \& Murrell, 2017). Nomination is usually based on academic rank, research, publication, and accomplishment (Kennedy, Lin \& Dickstein, 2001). Mauleón et al. (2013) observed a higher presence of women in editorial boards in fields with a higher share of women at the highest rank of the academic hierarchy. This paper therefore hypothesised that:

$H_{7}$ : The academic rank of the women has an influence on their presence in the editorial boards of hospitality journals. 
$H_{8}$ : Research productivity has an influence on the presence of women in the editorial boards of hospitality journals.

The methods that were used to study the objectives set in this paper are now presented.

\section{RESEARCH METHODS}

The extent of women's representation at editorship of hospitality journals was examined in this paper. To achieve this, an exploratory research design was used where manual data collection and quantitative analysis was employed.

Data collection was staggered in four phases. First, the choice of journals to include in the sample was based on extant literature. Hospitality journal rankings by McKercher, Law and Lam (2006), Mckercher (2012), Gursoy and Sandstrom (2016) were used. The top five leading hospitality journals identified by McKercher, Law and Lam (2006) based on peer ranking assessment of journal awareness and quality were, the Cornell Hospitality Quarterly, International Journal of Hospitality Management, Journal of Hospitality and Tourism Research, International Journal of Contemporary Hospitality Management and the Journal of Hospitality and Tourism Education. The list from McKercher (2012), based on an influence ratio, comprised of seven leading journals; International Journal of Hospitality Management, Journal of Hospitality \& Tourism Research, International Journal of Contemporary Hospitality Management, Scandinavian Journal of Hospitality and Tourism, Journal of Hospitality, Leisure, Sport and Tourism Education, Journal of Hospitality \& Tourism Research and the Cornell Hospitality Quarterly.

The last list of top scoring journals from Gursoy and Sandstrom (2016) were the International Journal of Hospitality Management, Journal of Hospitality and Tourism Research, Cornell Hospitality Quarterly, International Journal of Contemporary Hospitality Management, Journal of Hospitality Marketing and Management, Journal of Hospitality and Tourism Education, Journal of Foodservice Business Research and the International Journal of Hospitality and Tourism Administration, which were ranked based on the combined assessment of 563 researchers in hospitality and tourism.

The second step involved integrating the three lists, which resultantly led to a sample of 10 leading hospitality journals listed in alphabetical order. The acronyms of the journals as used in this study are parenthesized: 
Cornell Hospitality Quarterly (CHQ)

International Journal of Contemporary Hospitality Management (IJCHA)

International Journal of Hospitality and Tourism Administration (IJHTA)

International Journal of Hospitality Management (IJHM)

Journal of Foodservice Business Research (JFBR)

Journal of Hospitality and Tourism Education (JHTE)

Journal of Hospitality and Tourism Research (JHTR)

Journal of Hospitality Marketing and Management (JHMM)

Journal of Hospitality, Leisure, Sport and Tourism Education (JHLSTE)

Scandinavian Journal of Hospitality and Tourism (SJHT)

In the third step, journal descriptive information was recorded. The geographic region of affiliation, years of coverage (age) and the name of the publisher were retrieved from the Scimago Journal and Country Rank (SJR) and the Thomson Reuters Journal Citation Reports (JCR), which are research analytics tools. The geographic regions of affiliation were then classified into five based on the United Nations Geoscheme. The scheme is a system which divides the countries of the world into five regional groups of Europe, the Americas, Oceania, Asia and Africa (United Nations Statistics Division [UNSD], 2017).

In the last step, the editorial board lists were extracted from the official journal home pages. The size of the journal editorial board (measured by the total number of editorial members in the board) was ascertained manually. Each editorial board member was categorized in terms of their gender orientation. The gender of the editors was determined manually using various techniques such as photo searches, textual references based on gender-specific pronouns and the authors' inferences of an editor's name from common gender-specific names. The photo search on sites such as LinkedIn, Rocket Reach Search and Research Gate proved useful for ambiguous names. A manual search was adequate for a small sample as in our study. However, in longitudinal and large-scale gender studies, automated name-based approaches are ideal (Topaz \& Sen, 2016). The manual search was however limiting as it confined the gender classification into the binary female/male mode. However, this approach has been used successfully in other gender based studies (e.g. Amrein et al., 2011). 
The term editorship instead of editor was used, to infer to the editorial team, following Topaz and Sen (2016), as it relates to a position in the board rather than an individual. Using Topaz and Sen's (2016) criteria, editorships in the hospitality journals were classified into three; managing, editor and other. The Managing group, included all editorships with a leadership and managerial role. Titles such as editorin-chief, executive editors, managing editor, associate managing editor, associate editor, managing board member, regional editors, editorial assistants, coordinating editors and chief-editor were included in this category. The Editor category was comprised of titles such as editorial board member, editorial review member and editorial committee. The last group included titles such as honorary editor, advisory board, academic editor, founding board member, and editor emeritus (Topaz \& Sen, 2016).

The rank of the women editors as either professors or other (senior lecturer, researcher, director etc.) was retrieved from the journal home pages, university of affiliation webpages, LinkedIn, Rocket Reach Search or Research Gate. Lastly the research profiles of the women was measured using the $g$-Index, a bibliometric indicator of research productivity (Costas \& Bordons, 2008) retrieved from Google Scholar queries on Harzing's Publish and Perish Software version 6.

The data collected was further analyzed quantitatively using SPSS version 25 and STATA version 14. Journal characteristics were analyzed using descriptive information and frequencies. For gender parity, the percentage of women editorships was calculated. The relationship between women presence in the editorial boards, their characteristics and journal related factors such geographic affiliation, was studied using Spearman correlations, independent samples $t$ tests and multinomial logit regression analysis.

\section{PRESENTATION AND DISCUSSION OF MAIN FINDINGS}

This study analyses the editorial boards of ten leading hospitality journals, based on rankings by McKercher, Law and Lam (2006), Mckercher (2012) and Gursoy and Sandstrom (2016). The ten journals had 624 editorship positions at the time of research.

\section{JOURNAL CHARACTERISTICS}

The ten journals that were reviewed were established between 1960 (Cornel Hospitality Quarterly) and 2001 (SJHT). Five of the journals are published by Taylor and Francis, the rest by Elsevier (IJHM, JHLSTE), Emerald (IJCHM) and 
Sage (CHQ and JHTR). In terms of the journals' geographic affiliation, the Americas and Europe receive an equal share of five each.

\section{WOMEN EDITORSHIP POSITIONS}

The highest number of editorships in the boards was 134 (IJCHM) and the lowest was 15 (SJHT) (Figure 1). The IJCHM also had the highest number (at 40) of editorship positions held by women.

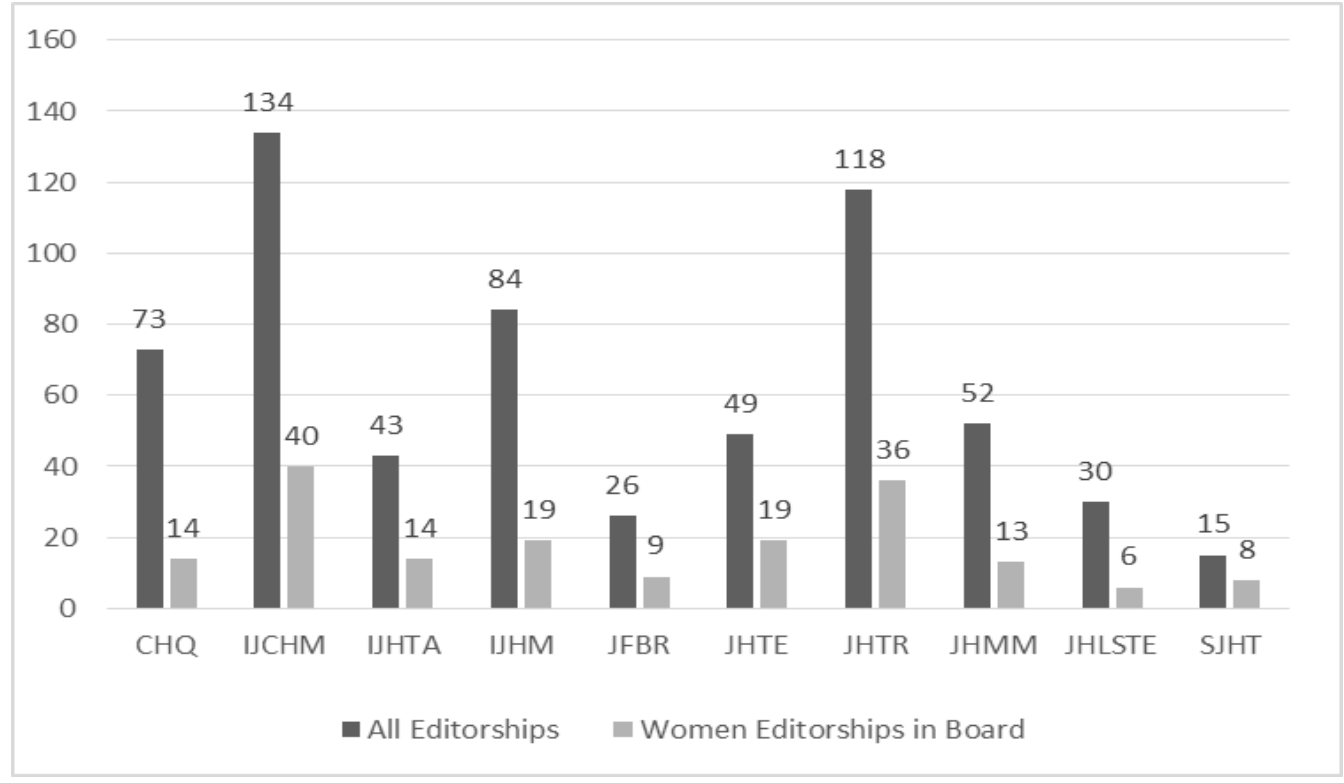

Fig. 1: Number of Editorships in Journal Editorial Boards

Source: Journal homepages

The percentage of women to men editorships in the boards ranged from 19\% (14 of 73 editorships) for the CHQ to 53\% in the SJHT (Figure 1). However, of all the 624 editorships, women held 178 positions (i.e. 29\%). The 178 positions were held by 132 women, as some (22\%) held more than one editorship position (i.e. the multiple editorships category). The highest number of positions held by a single member was six.

Of the 178 editorship positions, 79.2\% were held at editor level as advisory board members, editorial review or board members. A sizeable number $(19.1 \%)$ of the positions were held at management level, were women served as chief-editors, 
associate editors, regional editors, coordinating editors or co-editors. The other category comprised of $1.7 \%$ of the women. A further study of the 132 women revealed that the majority of them were affiliated with universities and institutions from the Americas (57.6\%). These were followed by those in Europe (22.7\%), Asia $(12.1 \%)$ and Oceania (7.6\%). There was no representation from Africa. The leading countries of affiliation in these regions were the United States of America (54.9\%), the United Kingdom (9.8\%), China (7.5\%), and Australia (4.5\%). The majority of the women $(84.1 \%)$ were professors.

Based on the findings, this study therefore fails to depart much from previous research because it confirms the existence of gender disparity in favour of men, where there is a low representation of women in hospitality journal editorial boards. At $29 \%$, editorship positions held by women were fairly low in number in comparison to their male counterparts. Secondly women were found to be under presented in comparison to their presence at authorship level. Although disaggregate results of women authors in hospitality do not exist, they represent $51 \%$ of the 3370 tourism and hospitality authors (whose gender could be ascertained on the CIRET and the TRINET databases (Munar et al. 2015). This scenario therefore supports the concept of vertical segregation or the 'glass ceiling' where there is a downward trend of women representation as responsibility levels increase (Mauleón, et al., 2013). Even the most prestigious position of chief-editor or co-editor was held by only five women.

\section{FACTORS THAT INFLUENCE THE PRESENCE OF WOMEN ON HOSPITALITY JOURNAL EDITORIAL BOARDS}

The factors that explain the presence (or absence) of women in journal editorial boards are multitude. Existing literature cites issues of implicit or explicit gender bias (Amrein et al., 2011), lack of innate intellectual talent by women editors (Meyer, Cimpian \& Leslie, 2015), lack mentorship and female role models (Amrein et al., 2011) and family responsibilities (Morton \& Sonnad, 2007). Some factors are journal related and may include the journal's desire to diversity the board (Topaz \& Sen, 2015), its size and the presence of a female editor-in-chief who acts as trailblazer (Mauleón, et al., 2013). In some cases, the editors' characteristics such as their academic performance, professional age or gender can be influential (Metz, Harzing \& Zyphur, 2016). Using a de-duplication process where individuals were analyzed (Topaz \& Sen, 2016), where possible, this study explored some of these factors but specifically analyzed the relationship between women editorships in the board with:

a) The presence of women chief editors $\left(\mathrm{H}_{1}\right)$ 
b) The presence of women at management editorship position $\left(\mathrm{H}_{2}\right)$

c) Size of the editorial board $\left(\mathrm{H}_{3}\right)$

d) Geographic region of the journal's affiliation $\left(\mathrm{H}_{4}\right)$

e) Geographic region of university affiliation $\left(\mathrm{H}_{5}\right)$

f) Age of the journal $\left(\mathrm{H}_{6}\right)$

g) Rank of the women editorial members $\left(\mathrm{H}_{7}\right)$

h) Level of research productivity of the women editorial members $\left(\mathrm{H}_{8}\right)$

Spearman's rank order correlations were conducted to test hypotheses $\mathrm{H}_{1}, \mathrm{H}_{2}, \mathrm{H}_{3}$ and $\mathrm{H}_{6}$, mainly because the sample size was small and the relationships between the variables were monotonic. There was no correlation between the presence of women in the editorial boards with the presence of women chief editors $\left(\mathrm{H}_{1}\right)$ and women in the journal management team $\left(\mathrm{H}_{2}\right)$ (Table 1). This finding supports a persistent perception of female misogyny in academia where successful women might not be helpful to other women in the workplace (Metz, Harzing \& Zyphur, 2016).

Tab. 1: Correlation Analysis $(\mathrm{n}=10)$

\begin{tabular}{|l|l|c|l|}
\hline \multicolumn{2}{|c|}{} & $\begin{array}{l}\text { Number of Women } \\
\text { Editorships in } \\
\text { Board }\end{array}$ \\
\hline $\begin{array}{l}\text { Spearman's } \\
\text { rho }\end{array}$ & Variable & $\begin{array}{c}\text { Correlation } \\
\text { Coef. }\end{array}$ & Sig. (2-tailed) \\
\cline { 2 - 4 } & Women Chief Editors $\left(\mathrm{H}_{1)}\right.$ & .056 & .878 \\
\cline { 2 - 4 } & $\begin{array}{l}\text { Women in Journal Management } \\
\text { Team (H) }\end{array}$ & .219 & .544 \\
\cline { 2 - 4 } & Size of Editorial Board $\left(\mathrm{H}_{3}\right)$ & $.762^{*}$ & .010 \\
\cline { 2 - 4 } & Age of Journal (Years) $\left(\mathrm{H}_{5}\right)$ & $.695^{*}$ & .026 \\
\hline
\end{tabular}

*. Correlation is significant at the 0.05 level (2-tailed).

However there was strong positive correlation between the size of the editorial board $\left(r_{\mathrm{s}}=.762, p<.05\right)$ and the age of the journal $\left(r_{s}=.695, p<.05\right)$ with the number of women editorships in the board. The size of the editorial board was positively correlated to the presence of women in the board, supporting findings by Metz and Harzing (2009) and Mauleón, et al. (2013). This finding backs existing empirical evidence that supports a positive association between a team's size and its heterogeneity suggesting that the larger the team, the more heterogeneous it would 
be (Metz, Harzing \& Zyphur, 2016). The age of the journal was also found to be positively correlated with the number of women in the boards. It would however be important in future, to assess how the leading hospitality journals studied in this paper, aligned their boards over the years in a bid (if any) to deal with such pressures.

To assess the influence of the geographic region of the journals' affiliation, classified as either America or Europe, on the presence of women in the editorial boards (and hence test $\mathrm{H}_{4}$ ), independent samples $t$ tests were conducted. The study concludes that there was no statistically significant difference between women membership in the boards of American hospitality journals with those from Europe $(t(8)=.322, p=.637)$.

Hypotheses $\mathrm{H}_{5}, \mathrm{H}_{7}$ and $\mathrm{H}_{8}$ were analyzed using multinomial regression which is amenable to small sample sizes where the dependent variables have more than two categories (Riggs, 2008). The model was used to analyze the relationship between editor features such as the academic rank (professor or other), the geographic region of the university or institution where the women are affiliated (America, Europe, Africa, Asia and Oceania) and research productivity (Low, medium or high $g$ index) and the four editorship positions (managing, editor, other and multiple).

The results are presented in Table 2 .

Tab. 2: Multinomial Logit Results

\begin{tabular}{|l|c|c|c|}
\hline Editor Features & $\begin{array}{c}\text { Management } \\
\text { Editorships }\end{array}$ & $\begin{array}{c}\text { Multiple } \\
\text { Editorships }\end{array}$ & Other Editorships \\
\hline$g$ Index (Medium) & .298 & 0.0825 & 0.510 \\
\hline$g$ Index (High) & -1.345 & $(1.060)$ & $(0.647)$ \\
\hline $\begin{array}{l}\text { Rank (Professor) } \\
\text { Region of }\end{array}$ & -0.436 & $\mathbf{1 . 4 9 6 *} *$ (7.19***** & $(0.937)$ \\
\hline $\begin{array}{l}\text { University } \\
\text { Affiliation (Europe) }\end{array}$ & $(0.658)$ & $(0.438)$ & $\mathbf{- 3 . 5 0 6 *}$ \\
\hline
\end{tabular}




\begin{tabular}{|c|c|c|c|}
\hline & $(0.584)$ & $(0.474)$ & $(2.213)$ \\
\hline \multirow[t]{2}{*}{$\begin{array}{l}\text { Region of } \\
\text { University } \\
\text { Affiliation (Asia) }\end{array}$} & -0.702 & 0.429 & $-14.37 * * *$ \\
\hline & (1.167) & $(0.723)$ & (0.799) \\
\hline \multirow[t]{2}{*}{$\begin{array}{l}\text { Region of } \\
\text { University } \\
\text { Affiliation } \\
\text { (Oceania) }\end{array}$} & .349 & 0.0501 & $-14.63 * * *$ \\
\hline & (1.037) & (1.128) & $(0.896)$ \\
\hline \multirow[t]{2}{*}{ Constant } & $-1.323^{*}$ & $-19.68 * * *$ & $-16.21 * * *$ \\
\hline & $(0.752)$ & $(0.586)$ & $(0.732)$ \\
\hline $\begin{array}{l}\text { Number of } \\
\text { Observations }\end{array}$ & 132 & 132 & 132 \\
\hline
\end{tabular}

Robust standard errors in parentheses $* * * \mathrm{p}<0.01, * * \mathrm{p}<0.05,{ }^{*} \mathrm{p}<0.1$

Reference Categories: 'Editor'; 'Low'; 'Other' and 'America'.

The results (Table 2) suggest that women with high research productivity (as measured by the $g$ index) are more likely to be nominated in:

1. The 'other' editorships category than the editor category $(16.69, p<0.01)$. The 'other' editorships category holds prestigious positions such as editor emeritus or honorary editor.

2. The multiple editorships category than the editor category $(1.496, p<0.1)$

The results also suggest that the professorial rank plays a key role for women who serve multiple editorships. They are more likely to serve in this category $(17.19, p<$ 0.01 ) than in the editor category. However, the professorial rank plays a lesser role for the 'other' editorships category $(-3.506, p<0.1)$ than the editor category.

In terms of the region of university affiliation, two key results exist (Table 2): 
1. Women who serve in the multiple editorships category (than in the editor category), are less likely to be affiliated with European than American universities or institutions $(-17.50, p<0.01)$.

2. Women serving in the 'other' editorships category (than in the editor category) are less likely to be affiliated with universities or institutions from Asia $(-14.37, p<0.01)$ or Oceania $(-14.63, p<0.01)$ than those from America.

All the other results from the model were statistically insignificant.

\section{CONCLUSION}

This study identified a low representation of women in hospitality journal editorial boards, suggesting the existence of gender disparity in favour of males. The low level of representation is in conformity with existing literature in other fields of study where gender disparity and imbalances have been noted. The study also realized some form of under representation relative to authors in tourism and hospitality databases. Because of the high status regarded of the journals studied, in hospitality as a field of study, and given the predominance of women at graduate level, and an almost equal share at authorship level, the authors expected a higher representation of women. The low representation of women in the boards, and their under representation relative to authorship in tourism and hospitality, disadvantages the journals of the wealth of comprehensive research experience that accompanies women appointments and also narrows the range of areas that are published (Metz, Harzing \& Zyphur, 2016). For Africa, with no representation, this call is even prominent and editorial committees should be encouraged to seek appointments from suitable women candidates if possible. Otherwise the dominance of representation from America and Europe, follows the traditional dominance of the two regions, in hospitality education (Chon, Barrows \& Bosselman, 2013) and tourism and hospitality education financing (Mahachi-Chatibura \& Nare, 2017). The two regions have been influential is channeling the growth of tourism and hospitality education and its financing.

Although this study could not isolate all the factors supporting the inclusion or exclusion of women, of those identified, only three were influential; the size of the editorial board, the age of the journal and the research productivity of the women in the editorial boards. The use of research productivity for advancement to an editorial management position is a merit based decision. This indicator should be used as a strategy to encourage junior researchers especially hospitality scholars from Africa as they endeavor to enrich their academic profiles. Journals with larger board sizes such as the IJCHM and the JHTR and are more likely to promote the presence of women on their boards. In terms of publication, having more women on the editorial 
boards of these journals, can assist in increasing the articles accepted for publication that are written by women (Kennedy, Lin \& Dickstein, 2001). Although more empirical evidence is required for this assertion, the presence of women in these journals is welcoming and more factors should be isolated on why this is so, from the editorial committee members and even the chief-editors.

\section{LIMITATIONS}

This study did not assess all hospitality journals but those regarded as influential and prestigious by teams of experts. The study is also cross sectional and contains records of boards as retrieved from journal home pages as of July 2018, to which alterations since that date may exist.

\section{REFERENCES}

Addis, E., Villa, P., 2003. The Editorial Boards of Italian Economics Journals: Women, Gender, and Social Networking. Feminist Economics, 9:1, 75-91, DOI: $10.1080 / 1354570032000057062$.

Amrein, K., Langmann, A., Fahrleitner-Pammer, A., Pieber, T. R., Zollner-Schwetz, I., 2011. Women Underrepresented on Editorial Boards of 60 Major Medical Journals, Gender Medicine. 8: 6, 378-387.

Costas, R., Bordons, M., 2008. Is g-index better than h-index? An exploratory study at the individual level. Scientometrics, 77:2, 267-288.

Brinn, T., Jones, M. J., 2007. Editorial boards in accounting: The power and the glory. Accounting Forum. 31, 1-25.

Chon, K.S., Barrows, C.W., Bosselman, R. H. 2013. Hospitality management education. London: Routledge.

Gollins, C.E., Shipman, A.R.., Murrell, D.F., 2017. A study of the number of female editors-in-chief of dermatology journals. International Journal of Women's Dermatology. 3, 185-188.

Gursoy. D., Sandstrom, J. K., 2016. An Updated Ranking of Hospitality and Tourism

Journals Journal of Hospitality \& Tourism Research. 40: 1, 3-18. 
Ioannidou, E., Rosania, A., 2015. Underrepresentation of Women on Dental Journal Editorial Boards. PLoS ONE 10(1): e0116630. DOI: 10.1371/ journal.pone.0116630.

Jagsi, R., Tarbell, N. J., Henault, L., Chang, Y., Hylek, E., 2008. The Representation of Women on the Editorial Boards of Major Medical Journals: A 35-Year Perspective. Archives of Internal Medicine. 168: 5, 544 - 547.

Kennedy, B.L., Lin, Y., Dickstein, L. J., 2001. Women on the Editorial Boards of Major Journals. Academic Medicine. 76, 849-851.

King, B., McKercher, B., Waryszak, R., 2003. A Comparative Study of Hospitality and Tourism Graduates in Australia and Hong Kong. International Journal of Tourism Research. 5, 409-420.

Ladkin, A., Weber. K., 2009. Tourism and Hospitality Academics: Career Profiles and Strategies. Journal of Teaching in Travel \& Tourism, 8:4, 373-393, DOI: 10.1080/15313220903152902.

Mahachi-Chatibura, D., Nare, A., 2017. A regional analysis of tourism education scholarships. Tourism management perspectives. 24, 155-165.

Mauleón, E., Hillán, L., Moreno, L., Gómez, L., Bordons, M., 2013. (2013) Assessing gender balance among journal authors and editorial board members. Scientometrics. 95, 87-114 DOI 10.1007/s11192-012-0824-4.

McKercher, B. 2012. Influence ratio: An alternate means to assess the relative influence of hospitality and tourism journals on research. International Journal of Hospitality Management, 31, 962-971.

McKercher, B., Law, R., Lam, T., 2006. Rating tourism and hospitality journals. Tourism Management, 27, 1235-1252.

Metz, I., Harzing, A., 2009. Gender Diversity in Editorial Boards of Management Journals. Academy of Management Learning \& Education. 8: 4, 540-557.

Metz, I., Harzing, A., 2012. An update of gender diversity in editorial boards: a longitudinal study of management journals. Personnel Review. 41:3, 283-300. DOI10.1108/00483481211212940. 
Metz, I., Harzing, A., Zyphur, M. J., 2016. Of Journal Editors and Editorial Boards: Who Are the Trailblazers in Increasing Editorial Board Gender Equality? British Journal of Management. 27, 712-726.

Meyer, M., Cimpian, A., Leslie, S., 2015. Women are underrepresented in fields where success is believed to require brilliance. Frontiers in Psychology. 6:1-12. DOI: 10.3389/fpsyg.2015.00235.

Morton, M. J., Sonnad, S. S., 2007. Women on Professional Society and Journal Editorial Boards. Journal of the National Medical Association. 99: 7, 764-771.

Munar, A.M. et. al., 2015. The gender gap in the tourism academy: statistics and indicators of gender equality. While Waiting for the Dawn. [Online] $<\mathrm{http}$ //www.tourismeducationfutures.org/about-tefi/gender-equity-in-thetourism-ac $>$ [3 July 2018].

Over, R., 1981. Representation of women on the editorial boards of psychology journals. American Psychologist 36:885-91.

Pan, Y., Zhang, J. Q., 2014The Composition of the Editorial Boards of General Marketing Journals. Journal of Marketing Education. 36:1, 33-44.

Riggs, D., 2008. Using Multinomial Logistic Regression Analysis to Develop a Model of Australian Gay and Heterosexual Sperm Donors' Motivations and Beliefs. International Journal of Emerging Technologies and Society.6: 2, 106 - 123.

Santero-Sanchez, R., Segovia-Pérez, M., Castro-Nuñez, B., Figueroa-Domecq, C., Talón-Ballestero, P., 2015. Gender differences in the hospitality industry: A Job quality index. Tourism Management.51, 234-246.

Topaz, C. M., Sen S., 2016. Gender Representation on Journal Editorial Boards in the Mathematical Sciences. PLoS ONE 11(8): e0161357.

doi:10.1371/journal.pone.0161357.

United Nations Statistics Division, 2017. Methodology Standard country or area codes for statistical use (M49). [Online]

$<$ https://unstats.un.org/unsd/methodology/m49/> [10 July 2018]. 
Willett, P., 2013. The Characteristics of Journal Editorial Boards in Library and Information Science International Journal of Knowledge Content Development \& Technology. 3:1, 5-17.

Woods, R. H., Viehland, D., 2000. Women in hotel management. Cornell Hotel and Restaurant Administration Quarterly, 41: 5, 51-54.

Young, M., 2017. How Women Became More Than Half of the Hospitality Workforce. Lodging. [Online]. <http://lodgingmagazine.com/how-women-becamemore-than-half-of-the-hospitality-workforce/ $>$ [12 July 2018]. 